\title{
MEMOIRS
}

\section{WILLIAM PHILLIPS}

THE career of Bill Phillips, as he was widely known in Institute circles, who died on 7 March, 1968 at the age of nearly 76, displayed high qualities in a variety of activities. But this austere statement gives little impression of a vivid personality, who was something more; namely, an original, with that creative faculty which flows from the ability to see the familiar from an unfamiliar angle, the condition indeed of progress and innovation. It was fitting, therefore, that he should have received one of the two Gold Medals awarded in 1964 - the other going to Wilfred Perks-under the new rules for such awards. As will become apparent, his natural abilities were such as to enable him to make his mark in a number of fields, including some in which our profession has latterly come to practise.

Phillips was born on 1 April, 1892, at Palmers Green in Middlesex, moving to Hatfield, Herts., early in 1902. He was educated at Hertford Grammar School (now Richard Hale School), serving in the school's Officers' Training Corps and obtaining the A and B certificates. In 1906 he obtained third place in the County Council Scholarship examination.

He joined the Prudential Assurance Company in 1908 in the Investment Department but later served in the Actuary's Office. He had had thoughts of becoming an architect but, happily for our profession, had lived next door, at Palmers Green, to Sir Joseph Burn, who was destined to become the General Manager of the Prudential, and who was a life-long friend of the family. Sir Joseph persuaded him to try to become an actuary. $\mathrm{He}$ accepted the challenge and he obtained the Fellowship in the month in which he became 21. He is believed to be the youngest at that time to have achieved the Fellowship and was said to have been the youngest actuary in the world.

On 4 August 1914 he volunteered for the Army but was rejected as 'unfit'. He was, however, sure that there would be a need for all who could contribute to the War effort and formed the City of London Volunteer Corps, of which he became Commandant. The Prudential allowed this body of men to train in the courtyard at Holborn Bars. In 1915 he became a subaltern in the Royal Garrison Artillery, and after two bouts of rheumatic fever and almost enforced retirement he persuaded the powers that be to allow him to stay in the Army at G.H.Q. in Birmingham controlling the Air defences. He there invented a predictor, for which he was subsequently awarded the military O.B.E. It is said to have effectively prevented Zeppelins from reaching Birmingham, and was not out-dated until shortly before the Second World War.

Demobilized in 1919, he joined the Wesleyan and General as Assistant Actuary. While with that office he went to the United States and Canada with A. L. Hunt, the then General Manager, to study insurance methods there, and helped to develop the Powers system in his office. He maintained contact with the Birmingham Actuarial Society for many years after he left Birmingham. In 1925, he went to the Manufacturers Life Insurance Company of Canada as Manager for Great Britain when they opened their U.K. office, being appointed Gencral Manager for Great Britain in 1935. He retired from life office management in 1946, and practised as a barrister until his death. He had been called to the Bar at the Middle Temple in 1928. He was a member of the Actuaries' Club, the Gallio Club (of which he was Chairman 1948-49), the Fellowship Club (of which he was President 1936-37) and the Argonauts.

His direct services to the Institute and the profession were considerable. He served on 
the Council from 1937 to 1944, and was appointed an Honorary Secretary from 1942 to 1944. He was also very active on the Students' Society, of which he was Chairman from 1937 to 1945, and he greatly helped the present writer with critical and stimulating comments on the draft of 'An Appreciation of the Students' Society, 1960. The First Fifty Years 1910-1960'. His helpfulness to younger members is still remembered. His earliest paper was one submitted to the Students' Society in February 1911 entitled 'Some notes on Indian Railways Securities' (J.S.S. 1, 25), when he was still at the Prudential.

The question of enlarging the scope of the profession had been the subject of a Special General Meeting of the Institute in October 1925 (J.I.A. 57, 88) after an intervention by the present writer at the Annual General Meeting in June 1924. Bill Phillips followed up by opening a discussion at a meeting of the Students' Society in December 1925 (J.S.S. 3, 66) entitled 'The Scope of the Actuary in Commerce and Industry', and later with a paper to the Institute itself in February 1927 (J.I.A. 58, 160)-. 'The Actuary in Commerce and Industry', based on actual problems upon which he had bcen called upon to advise, which, as he put it, could not be solved by those whom they had confronted, and had been brought to an actuary for solution.

Next, in 1934, there was a paper to the Institute on 'The Curve of Deaths' (J.I.A. 66, 17), a subject to which he was to return in 1954 with 'A Basic Curve of Deaths' (J.I.A. 80, 289). In 1936 came a crucial paper to the Institute entitled 'Binary Calculation' (J.I.A. $67,187)$, which but tardily received recognition as the earliest paper-after Babbage-in the chronology of computer development. On that occasion he displayed a model of a device to demonstrate the advantage of binary calculation in conjunction with octonary arithmetic. It is no longer challenged that his paper-and machine-occupy a distinctive place in the development of the modern computer and it is therefore remarkable how there was some failure to appreciate the priority of either his paper or his machine, the origin of the latter-day computer being attributed to work by others during the Second World War-unless there is a reference to Babbage. There were notable exceptions, however, including such an authority as Prof. Aitken, F.R.S., of Edinburgh University.

At our Annual General Meeting in June 1962, the President (J. H. Gunlake) reported that the above-mentioned device had been presented to the Science Museum, South Kensington, and had recently been exhibited along with a number of scientific inventions, at one of the Conversaziones held by the Royal Society, at which, as he put it, he

had the honour to contemplate with pride, and to demonstrate with some humility, this notable example of actuarial pioneering in the development of the electronic computer. (Year Book 1962/63, p. 245).

The President had also made an extended reference to Phillips's 1936 paper and the accompanying machine in the discussion on a paper in 1962 by R. G. Jecks on 'Administration of Group Life and Pensions Business by Computer' (J.I.A. 88, 175). His priority was still not appreciated in all quarters. Thus, an article in The Sunday Times (15 September 1965) on inventions in general elicited a correspondence in which our President (Sir Herbert Tetley) participated. The President's letter strove to do justice to Phillips as a pioneer innovator, referring to his 1936 paper and the accompanying device. There was also correspondence in The Times and in the Accountant which served to bring out his priority in the development of the modern computer. His satisfaction at this bclated recognition was complete when, as he informed the writer in January 1962, the Science Museum had managed to find room for his apparatus between part of Babbage's Analytical Engine and part of the ACE Pilot binary electronic computer which he and 
Womersley of the National Physical Laboratory had started to design in 1943. As he put it, his model

is therefore already available to the public gaze in a position which is chronologically and hereditarily correct, and will presently be appropriately labelled in such wise that the public will learn a little more about the activities of the Institute of Actuaries.

After he retired from the Manufacturers Life in 1946 he began to practise as a barrister specializing in the law of pension schemes of all kinds, a subject upon which he was to write extensively. Of his Pension Scheme Precedents (Sweet and Maxwell) published in 1957, the reviewer in J.I.A. $(83,69)$ said:

This is a book for the specialist in the pension field, but in spite of its title and purpose it is very readable.

This is a characteristic of almost all Bill Phillips's writings; his individual and independent approach was always in evidence. There was a First Supplement in 1961, which too received a favourable notice in J.I.A. $(\mathbf{8 8}, 125)$. He was also a contributor, for example, to the British Tax Encyclopedia and the British Tax Review on such diverse subjects as for example 'The Common Informer', 'The Salt Tax', 'The Cinque Ports' and 'The Origin of Income Tax', his articles being invariably erudite and spiced with wit. His qualities as a reviewer were well illustrated in his appreciation of Prof. Harry Street's Principles of the Law of Damages, 1962 (J.I.A. 88, 253).

Among other papers was one to the Institute dealing with 'Approximate Integration' (J.I.A. 77, 159), and another, jointly with C. H. L. Brown, to the 15 th International Congress on 'Uninsured Pension Schemes'. All his writings displayed marked thoroughness and considerable research into past precedents sometimes dating back for hundreds of years.

Of his contributions to discussions to the Institute, it can be said that they were usually pointed and arresting, and with fearless disregard for precedent and authority. Of the latter characteristic, who present on the occasion of E. H. Lever's paper in 1921 on the mortality of life tenants under reversions can forget his rebuke to a very senior member, and indeed prospective President, who had displayed difficulty in accepting Lever's conclusive statistical evidence as running counter to all his experience in this ficld. Phillips's intervention was happily diluted by the Editor in the following manner:

Mr E. W. Phillips said that the tables given in the paper had been calculated from the experience of twenty-one offices and it was useless to condemn the figures obtained merely because they were surprising (J.I.A. 53, 38).

The gasp in the Hall at the actual words can be remembered, with relish, after nearly half a century. People were not so outspoken in those days. Nevertheless, it must be recorded as a striking example of a certain 'directness' which was exhibited, not infrequently, in his contacts with the profession. This did not always commend him to his listeners, especially those with whom he might have felt constrained to cross swords. It may even have postponed the earlier recognition of his qualities. The profession owes much to Bill Phillips, and it is a happy thought that his abilities should ultimately have been recognized in signal fashion by the rarely awarded Gold Medal. The Times Obituary noticc was appropriately headed 'A Distinguished Actuary'. There was a memorial service in Temple Church.

William Phillips is survived by his wife, whom he married in 1933, and by two daughters: a son died in Canada.

F. A. A. MENZLER 